\title{
Varietal Differences in the Relationship between Maturation Characteristics, Storage Life and Ethylene Production in Peach Fruit
}

\author{
Takashi Haji*, Hideaki Yaegaki and Masami Yamaguchi \\ National Institute of Fruit Tree Science, NARO, Fujimoto, Tsukuba, 305-8605
}

\begin{abstract}
Summary
The time courses of fruit weight, ground color of skin ( $a^{*}$ value), flesh firmness, sugar content, titratable acidity and amount of ethylene produced were measured during growth, maturation and senescence of four peach cultivars (Prunus persica Batsch) with different keeping qualities. Special emphasis was placed on the relationships and differences among individual indices of maturation and the characteristics of ethylene production. In the melting-type cultivars 'Akatsuki', 'Kushigatahakuto' and 'Nagasawahakuho', increase in fruit size, changes in ground color, rise in sugar content and reduction in titratable acidity gradually proceeded after full bloom. After a cultivar-dependent period, postharvest ethylene production and softening were clearly accelerated. On-tree ethylene production occurred later. However, there were large varietal differences in the relationship between ethylene production and changes in the indices of maturation. In 'Kushigatahakuto', ethylene production and softening proceeded fruit enlargement, completion of changes in ground color, and the rapid rise in sugar content. In contrast, in 'Nagasawahakuho', which showed a slow and late softening, ethylene production started after attaining full size, accumulating near maximum sugar level and loss of ground color. In the stony hard-type cultivar 'Yumyeong', ethylene production and postharvest softening did not occur; the on-tree flesh firmness decreased to about $4.0 \mathrm{~kg}$. However, the trends in increase in fruit size, change in ground color, sugar accumulation and decreased in titratable acidity, were similar to those of the melting-type cultivars. From these results, we conclude that there are large varietal differences in the softening and maturation characteristics of peach fruit and that the genetics is determinant of these differences.
\end{abstract}

Key Words: ethylene, maturation, peach, softening.

\section{Introduction}

During maturation and ripening of fruits, enlargement, softening, changes in skin and flesh colors, accumulation of sugars, and lowering in acid content generally take place, and fruits become ready-to-eat (Gortner et al., 1967). Therefore, characteristics such as fruit size, flesh firmness, ground color of the skin, sugar content and titratable acidity are used as indices of maturity (Thompson, 1996). Flesh textures of peach (Prunus persica Batsch) are classified into melting, nonmelting and stony hard types (Connors, 1922; Connors, 1928; Yoshida, 1976). Most peach cultivars that are eaten flesh belong to the melting-type. The fruit of the meltingtype cultivars soften rapidly after harvest. Therefore, table peaches are generally harvested at the firm ripe rather than the eating ripe stage on trees. However, as the quality of early-harvested and postharvest-matured peaches is inferior to that of fruit that are fully matured

Received; May 22, 2003. Accepted; September 4, 2003.

* Corresponding author

Contribution No.1315 of the National Institute of Fruit Tree Science. on trees (Do et al., 1969; Robertson et al., 1992), it is desirable to harvest fruit as near to full maturation as possible. A difficulty arises in that the period suitable for the harvest of peach fruit of near-maturation stage is quite short. Crisosto (1994) indicated that the assessment of maturity from the combination of change in ground color and flesh firmness was a practical technique for the harvest of peach fruit with high eating quality and long storage life. One important breeding objective in peach is the improvement of storage life (Scorza and Okie, 1990; Kanato et al., 1980; Yamaguchi et al., 1996). Hence postharvest keeping quality is one of the important indices of fruit characteristics.

Recently, peach cultivars have changed markedly, and many new cultivars have been released in Japan. Among these newly-released cultivars, there are new types in which the flesh is hard even when ground color has changed. Thus, their maturation characteristics may differ from those of the traditional cultivars. We need to compare additional indices of ripening, beyond the rate of softening, to evaluate the keeping quality of different peach cultivars.

The ripening of fruits can be classified as climacteric 
and nonclimacteric types (Pratt and Goeschl, 1969; Abeles, 1973). In the climacteric type, ethylene is known to have key roles in the process of maturation, such that the control of ethylene has been discussed as a method improving storage life (Tucker, 1993; Grierson, 1998). Peach is a climacteric fruit (Biale and Young, 1981), and stony hard cultivars, which do not show postharvest ethylene production and softening, are sensitive to ethylene; they are subject to ethylene-induced softening (Haji et al., 2003). This suggests that ethylene is involved in the varietal differences in maturation and ripening characteristics of peach fruit. In this study, we compared maturity indices and ethylene production in four table peach cultivars with different storage life characteristics. Several new findings are reported.

\section{Materials and Methods}

This study was carried out in 1996, using the peach trees grown at the National Institute of Fruit Tree Science. The cultivars analyzed were 'Akatsuki', 'Kushigatahakuto', 'Nagasawahakuho' and 'Yumyeong'. 'Akatsuki', 'Kushigatahakuto' and 'Nagasawahakuho' are melting - type cultivars bred in Japan. 'Yumyeong' is a cultivar bred in Korea (Kim et al., 1978). It has been known that 'Yumyeong' is a stony hard type as previously reported (Haji et al., 2001).

Fruit of the stage III of development, which are in the processes of enlargement, maturation and senescence, were collected every 4 to 7 days from each cultivar. Fruit weight, change in ground color, flesh firmness, sugar content, titratable acidity and amount of ethylene production were measured on 4 fruit immediately after sampling. The rest of the collected fruit was stored at 25 ${ }^{\circ} \mathrm{C}$; the amount of ethylene they produced and their flesh firmness were measured every 2 days for 8 days using 3 fruit per sample.
As an index of change in ground color of the fruit skin, the $a^{*}$ value of the unpigmented area was measured with a spectrophotometer (Minolta, CM-2002). When ground color of peach fruit changed, the $\mathrm{a}^{*}$ value was more than -1.5. After removing the fruit skin in the equatorial area, the flesh firmness was measured with a fruit pressure tester (Italtest, FT011) with a cylindrical plunger $(8.0 \mathrm{~mm}$ diam.). The amount of ethylene produced was determined by incubating a fruit in a 1.5liter desiccator for $2 \mathrm{hr}$ at $25^{\circ} \mathrm{C}$. A $1.0-\mathrm{ml}$ gas sample that was withdrawn from the desiccator was injected into a gas chromatograph (Shimadzu, GC-9A) equipped with an activated alumina column and flame ionization detector. Sugar content was determined with a refractometer (Atago, PR-100), whereas, titratable acidity was expressed in malic acid equivalents after titration of acids in the juice with $0.1 \mathrm{~N} \mathrm{KOH}$.

\section{Results}

The time-courses of ethylene production and flesh firmness in the melting-type cultivars 'Kushigatahakuto', 'Akatsuki' and 'Nagasawahakuho' (Fig. 1, 2, $3)$ reveal that the on-tree flesh firmness gradually decreased with elapsed time after full bloom. Postharvest softening was not observed in immature fruit. However, postharvest softening became more marked after 75, 91 and 115 days after full bloom (DAFB) in 'Kushigatahakuto', 'Akatsuki' and 'Nagasawahakuho', respectively. After these dates the postharvest softening was clearly accelerated as compared to the on-tree softening. On-tree production of ethylene occurred 82, 109 and 129 DAFB in 'Kushigatahakuto', 'Akatsuki' and 'Nagasawahakuho', respectively. The amount of on - tree ethylene production increased slowly thereafter. In contrast, the postharvest fruit showed a very marked increase in the rate and total amounts of ethylene

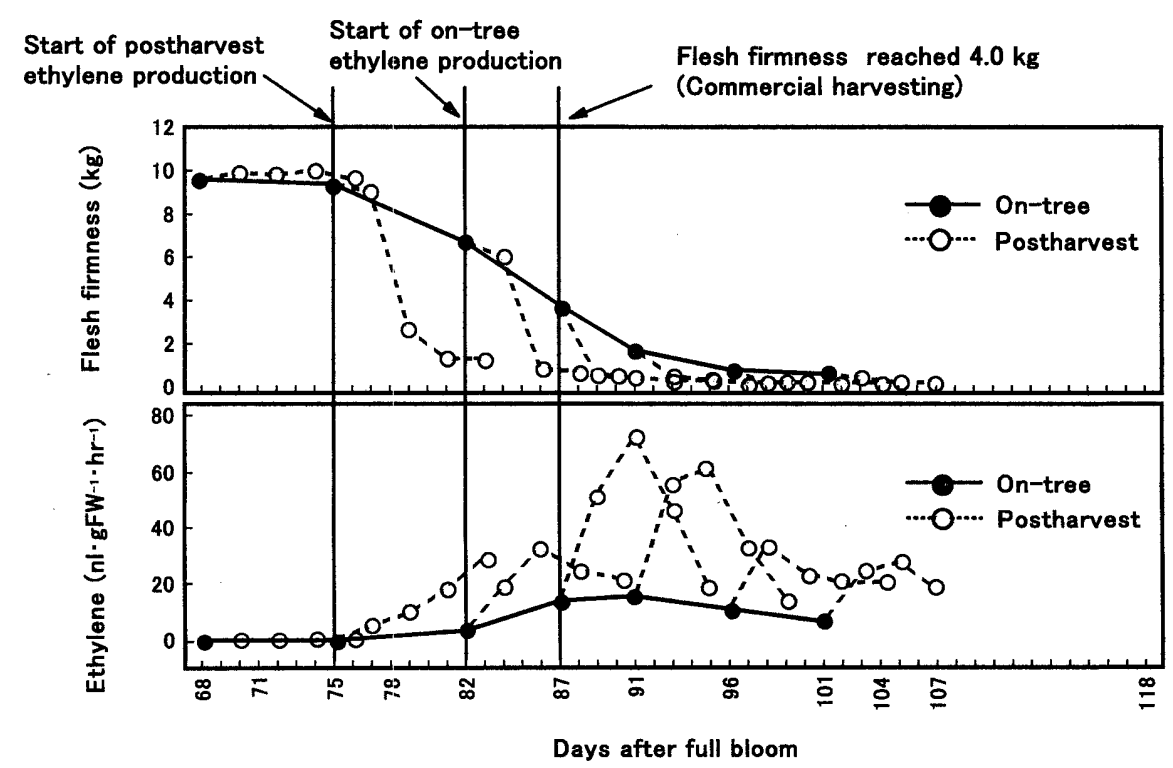

Fig. 1. On-tree and postharvest time courses of flesh firmness and amount of ethylene production in the melting-type cultivar 'Kushigatahakuto'. 


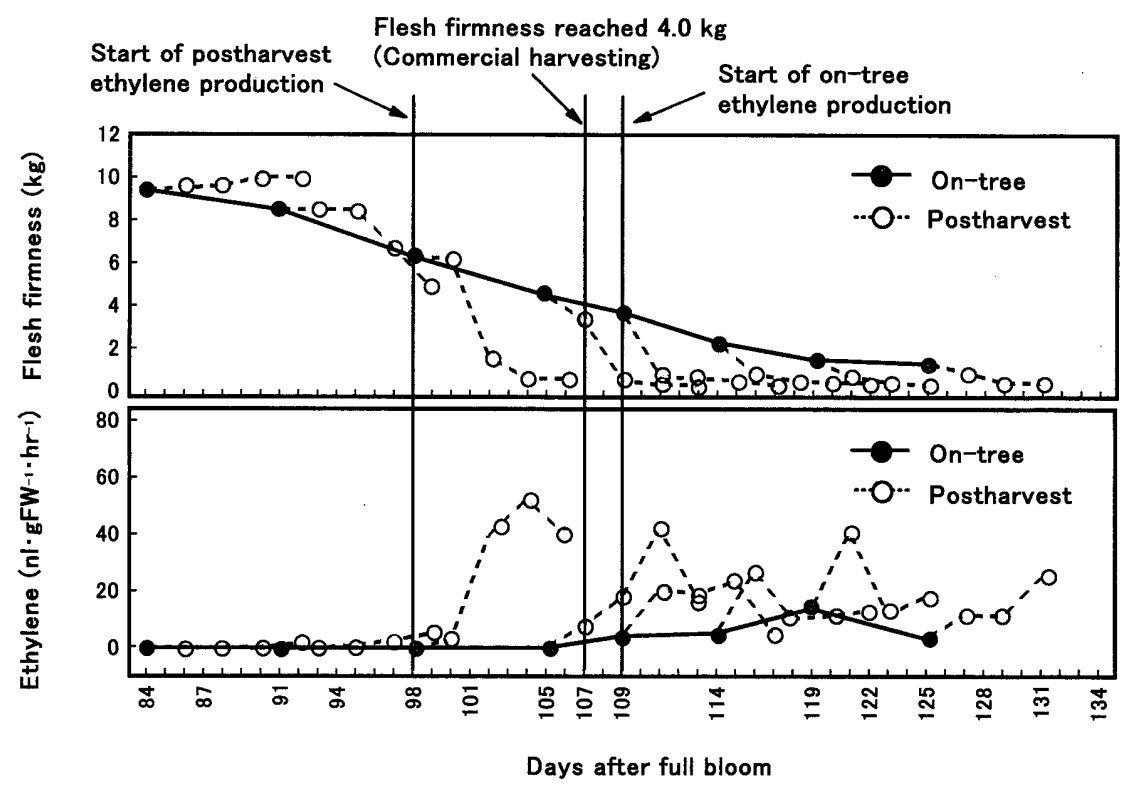

Fig. 2. On-tree and postharvest time courses of flesh firmness and amount of ethylene production in the melting-type cultivar 'Akatsuki'.

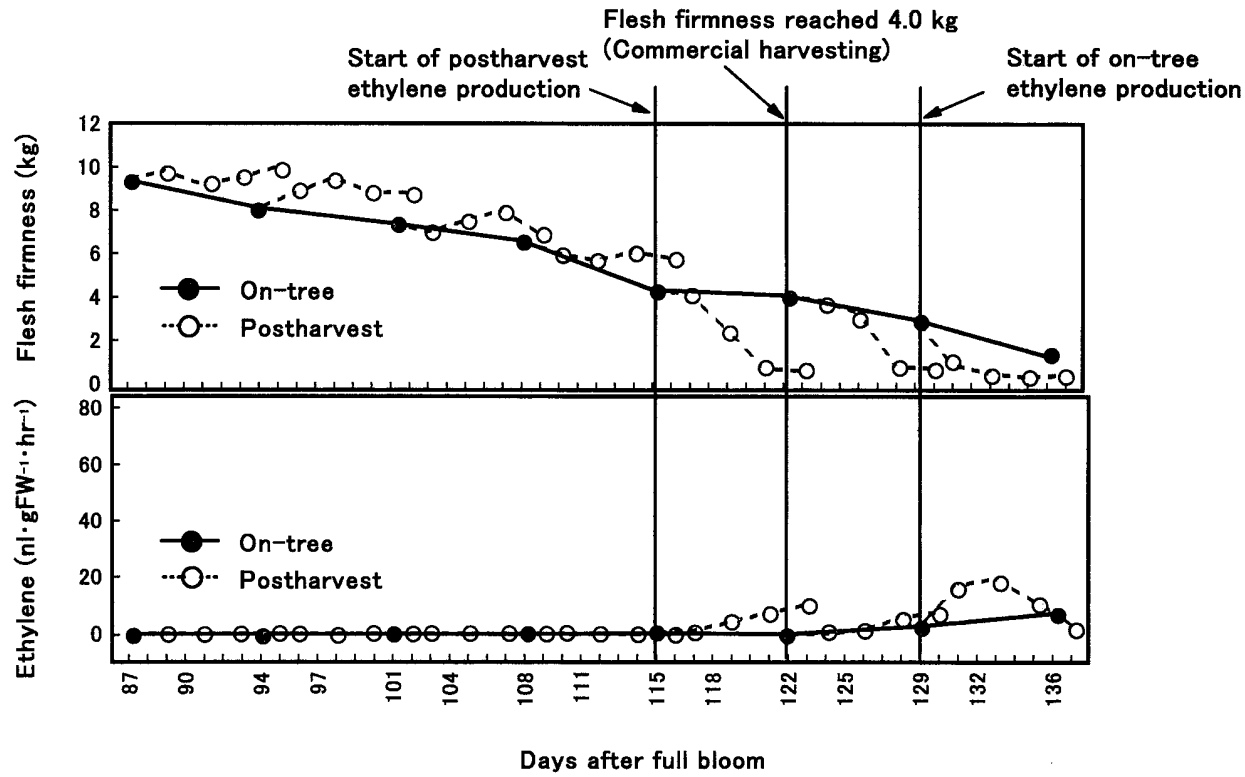

Fig. 3. On-tree and postharvest time courses of flesh firmness and amount of ethylene production in the melting - type cultivar 'Nagasawahakuho'.

produced. The increased ethylene production in the postharvest fruit was generally accompanied with a marked decrease in flesh firmness. Postharvest ethylene production and on-tree ethylene production were accelerated after on-tree flesh firmness decreased to $9.4 \mathrm{~kg}$ (75 DAFB) and $6.7 \mathrm{~kg}$ (82 DAFB), respectively, for 'Kushigatahakuto'; those factors decreased to $8.5 \mathrm{~kg}$ (91 DAFB) and $4.0 \mathrm{~kg}$ or less (109 DAFB) in 'Akatsuki'. Postharvest ethylene production did not occur in 'Nagasawahakuho' until flesh firmness dropped to $4.3 \mathrm{~kg}$ (115 DAFB); whereas on-tree ethylene production became detectable 14 days later (129 DAFB). On-tree softening was quite slow throughout these periods.

Time-courses of relative fruit weights, $a^{*}$ values of ground color, relative values of sugar content and titratable acidity in the three cultivars 'Kushigatahakuto',
'Akatsuki' and 'Nagasawahakuho' (Table 1, 2, 3) show that in all the cultivars, the increases in relative fruit weight and relative sugar content became slower as the days elapsed after full bloom, while the change in ground color and the lowering of titratable acidity proceeded. While the relative fruit weight to final weight at the time of onset of on-tree ethylene production was $52.2 \%$ in 'Kushigatahakuto', the corresponding value in 'Akatsuki' was $84.4 \%$ and that in 'Nagasawahakuho' was $98.2 \%$. In 'Kushigatahakuto', ethylene production started prior to the change in ground color, when the $\mathrm{a}^{*}$ value was -11.9. However, 'Akatsuki' and 'Nagasawahakuho' started ethylene production after the change in ground color, when the $\mathrm{a}^{*}$ values reached 0.5 and 2.5 , respectively. While the relative sugar contents in 'Akatsuki' and 'Nagasawahakuho' were higher than 
$90 \%$ of the final level, when the ethylene production started, the corresponding value in 'Kushigatahakuto' was $65.2 \%$. It was 9 days after the onset of ethylene production (91 DAFB) when the relative sugar content in 'Kushigatahakuto' exceeded $85.0 \%$. The flesh firmness at that time was less than $2.0 \mathrm{~kg}$ (Fig. 1). The titratable acidity in these cultivars was in the range of $0.20-0.26 \%$ when ethylene production started, showing that the process of acid decrease was almost completed. Relative to the other cultivars, onset of postharvest ethylene production was delayed in 'Nagasawahakuho'; fruit enlargement, change in ground color and sugar accumulation at that point were more advanced than those in 'Akatsuki'. Thus, there were large varietal differences in the relationship between ethylene production and the advancement of maturity indices. To clarify the situation, we compared relative fruit weight, ground color ( $a^{*}$ value), relative sugar content and titratable acidity in three melting-type cultivars when their respective flesh firmness reached $4.0 \mathrm{~kg}$, a stage often regarded as suitable for commercial harvesting (Table 4). At this stage, the titratable acids had decreased in all cultivars. 'Kushigatahakuto' was still growing in size and some of its ground color remained. Moreover, production of a large amount of ethylene was observed even though this stage preceded the rapid increase of sugar content. On the other hand, 'Akatsuki' and 'Nagasawahakuho' had almost reached full size and maximum sugar accumulation. Although 'Akatsuki' started ethylene production with partially remaining ground color, 'Nagasawahakuho' did not evolve ethylene even with the full change in ground color.

Table 1. Relative fruit weight, $a^{*}$ value, relative sugar content and titratable acidity at different stage of development and maturation in 'Kushigatahakuto'.

\begin{tabular}{ccccc}
\hline \hline Days after full bloom & $\begin{array}{c}\text { Relative fruit weight } \\
(\%)\end{array}$ & $\begin{array}{c}\text { Ground color } \\
\left(\mathrm{a}^{*} \text { value }\right)\end{array}$ & $\begin{array}{c}\text { Relative sugar content } \\
(\%)\end{array}$ & $\begin{array}{c}\text { Titratable acidity } \\
(\%)\end{array}$ \\
\hline 68 & 24.1 & -15.7 & 61.6 & 0.52 \\
$75^{\mathrm{y}}$ & 32.3 & -15.7 & 61.6 & 0.52 \\
$82^{\mathrm{x}}$ & 52.2 & -11.9 & 65.2 & 0.25 \\
87 & 65.2 & -6.5 & 68.8 & 0.15 \\
91 & 83.3 & -3.0 & 89.1 & 0.14 \\
96 & 94.9 & -2.8 & 85.5 & 0.15 \\
101 & $100.0^{\mathrm{w}}$ & 2.3 & $100.0^{\mathrm{v}}$ & 0.15 \\
\hline
\end{tabular}

${ }^{z} 100 \times$ (observed value/maximum value)

${ }^{y}$ Start of postharvest ethylene production.

${ }^{x}$ Start of on-tree ethylene production.

${ }^{\mathrm{w}}$ Maximum value of fruit weight was $293.3 \mathrm{~g}$.

${ }^{v}$ Maximum value of soluble solid content was $13.8 \%$.

Table 2. Relative fruit weight, a* value, relative sugar content and titratable acidity at different stage of development and maturation in 'Akatsuki'.

\begin{tabular}{ccccc}
\hline \hline Days after full bloom & $\begin{array}{c}\text { Relative fruit weight }{ }^{2} \\
(\%)\end{array}$ & $\begin{array}{c}\text { Ground color } \\
\left(\mathrm{a}^{*} \text { value }\right)\end{array}$ & $\begin{array}{c}\text { Relative sugar content } \\
(\%)\end{array}$ & $\begin{array}{c}\text { Titratable acidity } \\
(\%)\end{array}$ \\
\hline 84 & 31.6 & -14.4 & 60.7 & 0.79 \\
91 & 34.6 & -13.3 & 70.7 & 0.46 \\
$98^{\mathrm{y}}$ & 71.3 & -12.0 & 82.8 & 0.36 \\
105 & 84.8 & -7.1 & 91.4 & 0.28 \\
$109^{\mathrm{x}}$ & 84.4 & 0.5 & 92.1 & 0.26 \\
114 & 87.9 & 0.7 & 98.6 & 0.24 \\
119 & 93.4 & 1.1 & 99.2 & 0.20 \\
125 & $100.0^{\mathrm{w}}$ & 3.1 & $100.0^{\mathrm{v}}$ & 0.15 \\
\hline
\end{tabular}

\footnotetext{
${ }^{2} 100 \times$ (observed value/maximum value).

${ }^{\mathrm{y}}$ Start of postharvest ethylene production.

${ }^{x}$ Start of on-tree ethylene production.

${ }^{\mathrm{w}}$ Maximum value of fruit weight was $258.7 \mathrm{~g}$.

${ }^{v}$ Maximum value of soluble solid content was $13.9 \%$.
} 
Table 3. Relative fruit weight, $a^{*}$ value, relative sugar content and titratable acidity at different stage of development and maturation in 'Nagasawahakuho'.

\begin{tabular}{ccccc}
\hline \hline Days after full bloom & $\begin{array}{c}\text { Relative fruit weight }{ }^{2} \\
(\%)\end{array}$ & $\begin{array}{c}\text { Ground color } \\
\left(\mathrm{a}^{*} \text { value }\right)\end{array}$ & $\begin{array}{c}\text { Relative sugar content } \\
{ }^{2}\end{array}$ & $\begin{array}{c}\text { Titratable acidity }^{(\%)} \\
(\%)\end{array}$ \\
\hline 87 & 20.4 & -14.8 & 61.6 & 0.76 \\
94 & 26.2 & -14.3 & 72.9 & 0.50 \\
101 & 41.4 & -12.8 & 79.7 & 0.40 \\
108 & 61.8 & -8.2 & 78.9 & 0.36 \\
$115^{\mathrm{y}}$ & 91.9 & -4.6 & 90.2 & 0.20 \\
122 & 90.7 & 0.7 & 88.7 & 0.22 \\
$129^{\mathrm{x}}$ & 98.2 & 2.5 & 99.2 & 0.21 \\
136 & $100.0^{\mathrm{w}}$ & 3.9 & $100.0^{\mathrm{v}}$ & 0.20 \\
\hline
\end{tabular}

${ }^{z} 100 \times$ (observed value/maximum value).

${ }^{y}$ Start of postharvest ethylene production.

${ }^{x}$ Start of on-tree ethylene production.

${ }^{\mathrm{w}}$ Maximum value of fruit weight was $275.1 \mathrm{~g}$.

${ }^{v}$ Maximum value of soluble solid content was $13.3 \%$.

Table 4. Relative fruit weight, $a^{*}$ value, ethylene production, relative sugar content and titratable acidity in melting-type cultivars at the stage when flesh firmness reached $4.0 \mathrm{~kg}$.

\begin{tabular}{lccccc}
\hline \hline Cultivar & $\begin{array}{c}\text { Relative fruit weight }{ }^{2} \\
(\%)\end{array}$ & $\begin{array}{c}\text { Ground color } \\
\left(\mathrm{a}^{*} \text { value }\right)\end{array}$ & $\begin{array}{c}\text { Ethylene } \\
\left(\mathrm{nl} \cdot \mathrm{gFW}^{-1} \cdot \mathrm{hr}^{-1}\right)\end{array}$ & $\begin{array}{c}\text { Relative sugar content } \\
(\%)\end{array}$ & $\begin{array}{c}\text { Titratable acidity } \\
(\%)\end{array}$ \\
\hline Kushigatahakuto & 65.2 & -6.5 & 14.1 & 68.8 & 0.15 \\
Akatsuki & 84.6 & -3.3 & 2.2 & 91.8 & 0.27 \\
Nagasawahakuho & 90.7 & 0.7 & 0.0 & 88.7 & 0.22 \\
\hline
\end{tabular}

${ }^{2} 100 \times$ (observed value/maximum value).

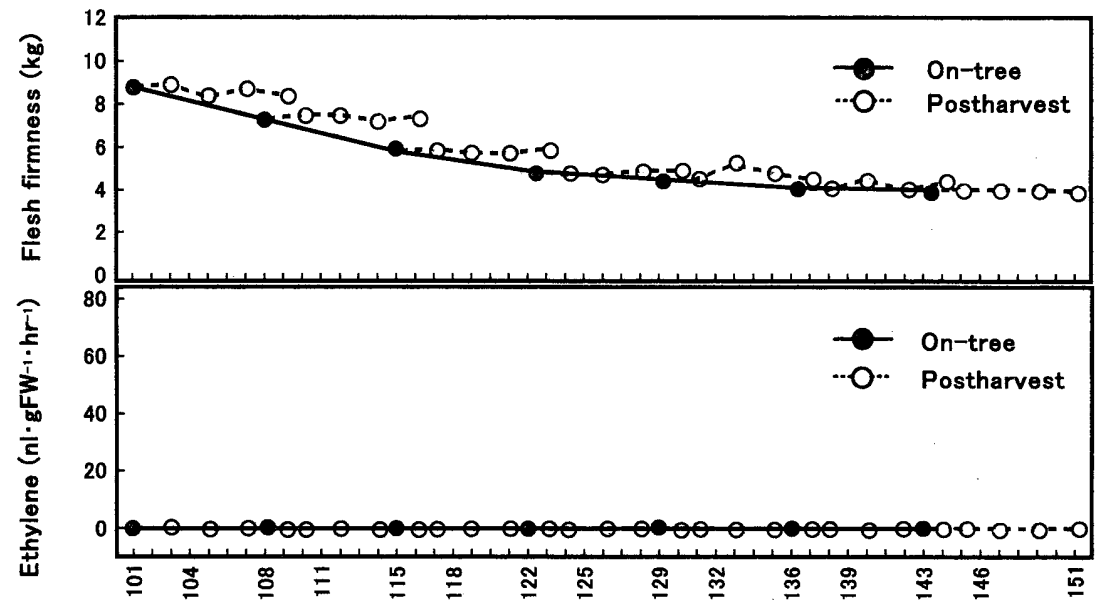

Days after full bloom

Fig. 4. On-tree and postharvest time courses of flesh firmness and amount of ethylene production in the stony hard cultivar 'Yumyeong'.

The similar results were obtained in the stony hardtype cultivar 'Yumyeong' (Fig. 4, Table 5). In this cultivar, unlike 'Kushigatahakuto', 'Akatsuki' and 'Nagasawahakuho', ethylene production and postharvest softening did not occur. The on-tree decrease in flesh firmness was moderate, dropping to about $4.0 \mathrm{~kg}$. On the other hand, the increase in fruit weight, the change in ground color, the increase in sugar content and the drop in titratable acidity were similar to those of the meltingtype cultivars. Fruit enlargement, the change in ground color, the accumulation of sugars and the drop in acidity were almost complete 129 DAFB.

\section{Discussion}

Although the level of ethylene production has been regarded as a key factor determining varietal differences 
Table 5. Relative fruit weight, $\mathrm{a}^{*}$ value, relative sugar content and titratable acidity at different stage of development and maturation in 'Yumyeong'.

\begin{tabular}{|c|c|c|c|c|}
\hline Days after full bloom & $\begin{array}{c}\text { Relative fruit weight }{ }^{2} \\
(\%)\end{array}$ & $\begin{array}{c}\text { Ground color } \\
\text { (a* value) }\end{array}$ & $\begin{array}{c}\text { Relative sugar content } \\
\text { (\%) }\end{array}$ & $\begin{array}{c}\text { Titratable acidity } \\
(\%)\end{array}$ \\
\hline 101 & 39.6 & -14.2 & 76.7 & 0.60 \\
\hline 108 & 53.1 & -9.3 & 77.5 & 0.44 \\
\hline 115 & 60.1 & -7.3 & 80.8 & 0.27 \\
\hline 122 & 81.8 & -3.1 & 88.3 & 0.31 \\
\hline 129 & 93.0 & 0.2 & 91.6 & 0.27 \\
\hline 136 & 97.4 & 1.5 & 95.6 & 0.25 \\
\hline 143 & $100.0^{\mathrm{y}}$ & 2.2 & $100.0^{\mathrm{x}}$ & 0.23 \\
\hline
\end{tabular}

${ }^{2} 100 \times$ (observed value/maximum value).

${ }^{\mathrm{y}}$ Maximum value of fruit weight was $268.0 \mathrm{~g}$.

${ }^{\mathrm{x}}$ Maximum value of soluble solid content was $12.0 \%$.

in the storage life of melons (Kitamura et al., 1975; Kendall and Ng, 1988) and apples (Yoshioka et al., 1989), our maturity indices did not always advance synchronously and maturation characteristics differed appreciably among peach varieties. In 'Kushigatahakuto' ethylene production started in the early stage of fruit development, the softening of flesh preceded the increase in fruit size, the change in ground color and sugar accumulation. In 'Nagasawahakuho', a late ethylene producer, the softening of flesh started after the increase in fruit size, the change in ground color, sugar accumulation and the drop in acidity occurred. In 'Yumyeong', ethylene production and postharvest softening did not occur, but the increase in fruit size, change in ground color, rise in sugar content and decrease in titratable acids advanced normally. This indicates that for peach, unlike melon and apple, the time of onset of ethylene production varied and determining the keeping quality and maturation characteristics. Therefore, we conclude that the onset of ethylene production is a key criterion in the breeding and selection of new peach cultivars. In 'Yumyeong', the on-tree flesh firmness gradually decreased with increase in fruit size while harvested fruit did not soften, which suggests that in addition to the ethylene-regulated softening, fruit enlargement may also affect when softening of on-tree fruit takes place.

Transgenic plants in which ethylene production is almost completely suppressed have been obtained in tomato (Hamilton et al., 1990; Oeller et al., 1991) and melon (Ayub et al., 1996; Guis et al., 1997). Softening and coloration are strongly inhibited in the fruits of these transgenic plants. Genetic engineering opens a gate to the possibility of longer storage life for fruits, thus, is a focus of much attention. For commercial applications, the development of a technique that suppresses softening but not other maturation processes, is desirable (Grierson, 1998; Bommineni, 2000). On the other hand, this study showed that there are wide varietal differences in the capacity for ethylene production, and that the time of onset of ethylene production and of softening are closely related. We demonstraeted that even when ethylene production is delayed or suppressed, the other major indices of maturation of peach fruit, besides softening, proceeds normally. These findings suggest that the possibility of improving the keeping quality of peach fruit, by genetically controlling the onset of ethylene production exists. It is also expected to be possible to achieve larger fruit size and higher fruit quality by delaying the start of ethylene production, as there are cultivars, such as 'Kushigatahakuto' that start ethylene production and softening during the enlargement of fruit size or before the rapid rise in sugar content.

\section{Literature Cited}

Abeles, F. B. 1973. Ethylene in plant biology. p. 161-178. Academic Press, New York.

Ayub, R., M. Guis, M. B. Amor, L. Gillot, J. P. Roustan, A. Latche, M. Bouzayen and J. C. Pech. 1996. Expression of ACC oxidase antisense gene inhibits ripening of cantaloupe melon fruits. Nature Biotech. 14: 862-866.

Biale, J. B. and R. E. Young. 1981. Respiration and ripening in fruits - retrospect and prospect. p. 1-39. In: J. Friend and M. J. C. Rhodes (eds.). Recent advances in the biochemistry of fruits and vegetables. Academic Press, London.

Bommineni, V. R., H. Mathews, S. K. Clendennen, W. Wagoner, V. Dewey, J. Kellogg, S. Peters, W. Matsumura, M. Pieper, M. Kramer, D. R. Wagner. 2000. Genetic engineering of fruits and vegetables with the ethylene control gene encoding $\mathrm{s}$-adenosylmethionine hydrolase (SAMase). p. 206-214. In: A. D. Arencibia (ed.). Developments in plant genetics and breeding 5 plant genetic engineering towards the third millennium. Elsevier Science, Amsterdam.

Connors, C. H. 1922. Peach breeding - a summary of results. Proc. Amer. Soc. Hort. Sci. 19: 108-115.

Connors, C. H. 1928. Further notes on peach breeding. Proc. 
Amer. Soc. Hort. Sci. 25: 125-128.

Crisosto, C. H. 1994. Stone fruit maturity indices: a descriptive review. Postharvest news and information 5: 6568.

Do, J. Y., D. K. Salunkhe and L. E. Olson. 1969. Isolation, identification and comparision of the volatiles of peach fruit as related to harvest maturity and artificial ripening. J. Food Sci. 34: 618-621.

Gortner W. A., G. G. Dull and B. H. Krauss. 1967. Fruit development, maturation, ripening and senescence: a biochemical basis for horticultural terminology. HortScience 2: $141-144$.

Grierson, D. 1998. Manipulation of fruit ripening by genetic modification. p. 109-124. In: K. Lindsey (ed.). Transgenic plant research. Harwood Academic Publishers, Amsterdam.

Guis, M., R. Botondi, M. Ben-Amor, R. Ayub, M. Bouzayen, J. C. Pech and A. Latche. 1997. Ripeningassociated biochemical traits of cantaloupe charentais melons expressing an antisense ACC oxidase transgene. J. Amer. Hort. Sci. 122: 748-751.

Haji, T., H. Yaegaki and M. Yamaguchi. 2001. Changes in ethylene production and flesh firmness of melting, nonmelting and stony hard peaches after harvest. J. Japan. Soc. Hort. Sci. 70: 458-459.

Haji, T., H. Yaegaki and M. Yamaguchi. 2003. Softening of stony hard peach by ethylene and the induction of endogenous ethylene by 1 -aminocyclopropane - 1-carboxylic acid (ACC). J. Japan. Soc. Hort. Sci. 72: 212217.

Hamilton, A. J., G. W. Lycett and D. Grierson. 1990. Antisense gene that inhibits synthesis of hormone ethylene in transgenetic plants. Nature 346: 284-287.

Kanato K., M. Yoshida, A. Kurihara, T. Sato, R. Harada and H. Kyotani. 1980. New peach cultivar 'Akatsuki'. Bull. Fruit Tree. Res. Sta. A7: 1-6.

Kendall, S. A. and T. J. Ng. 1988. Genetic variation of ethylene production in harvested muskmelon fruits. HortScience 23: 759-761.
Kim, Y. H., M. D. Cho, D. K. Lee and Y. S. Yu. 1978. The new peach cultivar 'Yumyeong'. Res. Rep. Office Rural Dev. Hort. and Agr. Eng. 20: 1-5.

Kitamura, T., T. Umemoto, T. Iwata and T. Akazawa. 1975. Studies on the storage of melon fruits. II Changes of respiration and ethylene production during ripening with reference to cultivars. J. Japan. Soc. Hort. Sci. 44: 197-203.

Oeller, P. W., L. M. Wong, L. P. Taylor, D. A. Pike and A. Theologis. 1991. Reversible inhibition of tomato fruit senescence by antisense RNA. Science 254: 437-439.

Pratt, H. K. and J. D.Goeschl. 1969. Physiological roles of ethylene in plants. Ann. Rev. Plant Physiol. 20: 541584.

Robertson, J. A., F. I. Meredith, W. R. Forbus and B. G. Lyon. 1992. Relationship of quality characteristics of peaches (cv. Loring) to maturity. J. Food. Sci. 57: 1401 $-1404$.

Scorza, R. and W. R. Okie. 1990. Peaches (Prunus). p. 177231. In: J. N. Moore and J. R. Ballington Jr. (eds.). Genetic resources of temperate fruit and nut crops. Acta Hortic. 290.

Thompson, A. K. 1996. Postharvest technology of fruit and vegetables. p. 26-55. Blackwell Science, Oxford.

Tucker, G. A. 1993. Introduction. p. 1-51. In: G. B. Seymour, J. E. Taylor and G. A. Turker (eds.). Biochemistry of fruit ripening. Chapman \& Hall, London.

Yamaguchi M., H. Kyotani, M. Yoshida, Y. Nakamura, K. Nishimura, T. Haji, T. Kozono and H. Fukuda. 1996. New peach cultivar 'Akizora'. Bull. Fruit Tree. Res. Sta. 29: 1-13.

Yoshida, M. 1976. Genetical studies on the fruit quality of peach varieties. III Texture and keeping quality. Bull. Fruit Tree Res. Sta. A3: 1-16.

Yoshioka, H., K. Aoba and M. Fukumoto. 1989. Relationships between quantitative and physiological changes during storage and maturation in apple fruit. J. Japan Soc. Hort. Sci. 58: $31-36$. 
モモ果実における成熟特性と日持ち性およびエチレン生成との関係の品種間差異

土師 岳・八重垣英明・山口正己

農業技術研究機構果樹研究所 $305-8605$ 茨城県つくば市

摘要

日持ち性が異なる生食用モモ品種について, 果実の肥大, 成熟および老化の過程を通して果実重, 果皮の地色の $\mathrm{a}^{*}$ 値, 果肉硬度, 糖度, 滴定酸含量, エチレン生成量の推移を調査 し, 熟度の指標の相互関係すなわち成熟特性の差異とエチレ ン生成特性との関連を検討した。溶質品種の ‘あかつき”, “櫛形白桃”および “長沢白鳳”はいずれも満開後日数の経過 之ともに果実肥大, 地色の抜け, 糖度の上昇, 滴定酸含量の 低下が進み, 特定の日以降収權によりエチレン生成と軟化が 明膫に促進されるようになった後，樹上でのエデレン生成が 認められるようになった。しかしエチレン生成と熟度の指 標の進行との間には大きな品種間差異が見出され, “概形白
桃’は果実肥大の途中で地色が残り，糖度が急速に増加する 前であってもエチレンを多く生成し軟化が進んだのに対し て, 軟化が遅延する ‘長沢白鳳”では果実肥大之糖度の上昇 を終え地色が抜けた後にエチレン生成が始まった，また硬 肉品種の 有明”ではエチレン生成之収穫後の軟化が認めら れず，樹上での果肉硬度は $4.0 \mathrm{~kg}$ 前後までしか低下しなか ったものの, 果実肥大, 地色の抜け, 糖度の上昇, 滴定酸含 量の低下は溶質品種之同様に進んでいた．以上の結果から, モモでは果実の軟化特性とともに成熟特性にも大きな品種 間差異が認妙られ，その発現にはエチレン生成開始時期の遗 伝的差異が重要な働きをしていると考えられた。 